\title{
The Effect of Capital Structure, GCG, CSR, Firm’s Size on Market Value through Earnings Per Share in Banking Sector
}

Kahlil Fauzan* and Dr. Adi Kuswanto

Department of Economics, MMSI, Gunadarma University Depok, Jawa Barat, Indonesia

\begin{abstract}
The objective of this research are to analyst the effect of capital structure, corporate governance, corporate social responsibility, firm's size on earnings per share and to analyst the effect of earnings per share on market value. The subject of this research is the banking sector entities listed on the Indonesia Stock Exchange in the year 2008 and reported self-assessment of good corporate governance from the year 2008 up to 2015 also did not experience any losses resulting in earnings per share negative from the year 2008 up to 2015. The result shows that capital structure, good corporate governance, corporate social responsibility and firm's size have influence on earnings per share. The relationship between capital structure with earnings per share inversely proportional. The relationship between the good corporate governance with earnings per share is directly proportional. The relationship between corporate social responsibility with earnings per share inversely proportional. The relationship between firm's size with earnings per share is directly proportional.

Earnings per share have influence on market value. The relationship between earnings per share and market value is directly proportional. Earnings per share reflects the book value reported by the bank, the real value of the bank is the market value. It can be indicated that the capital market in Indonesia gives higher value to the bank due to the strength of bank income. If the bank has profits consistently will have a market value greater than the book value of the bank.
\end{abstract}

Keywords: Capital structure; Good corporate governance; Corporate social responsibility; Firm's size; Earnings per share; Market value

\section{Introduction}

In the current era, for people who live in developing countries, hearing the word of "bank" is not a strange word. Bank has been a partner in order to meet all their financial needs. Bank serve as institutions that perform various financial transactions related to such, where securing money, make investments, remittances, make payments or perform billing. Besides, the role of banks greatly affected a country's economic activity. Bank can be regarded as the blood of a country's economy. Therefore, the progress of a bank in one country can also be used as a measure of progress of the country concerned. The more developed a country, the greater the role of banks in controlling the country's economy. In developing countries, an understanding of the new bank piecemeal. Most people only understand the extent of a bank to borrow and borrow money alone. In fact, sometimes some people do not understand the bank as a whole, so the view of the bank often interpreted incorrectly. All this is understandable since the introduction of the banking world as a whole on the community is minimal, so it is not surprising that the collapse of the banking world is inseparable from his lack of understanding of banking in the country managers in understanding the banking world as a whole.

Financial institutions, in particular banks, have come under increasing pressure, since the sub-prime mortgage crisis and the following credit crunch to take a more long-term view of their investors' business interests and to acknowledge and respond to their obligations to society [1]. Due to the extensive negative external effects poorly managed and controlled banks can impose on society, the perception of the firms' corporate social responsibility (CSR) activities is important not only for investors' and customers' risk assessment, but also for regulators' good-will and for the public's confidence in the financial system.

An unprecedented large number of financial institutions collapsed or were bailed out by governments during the global financial crisis of
2007-2008. The failure of these institutions resulted in a freeze of global credit markets and required government interventions worldwide. While the macroeconomic factors (e.g., loose monetary policies) that are at the roots of the financial crisis affected all firms [2], some firms were affected much more than others. Recent studies argue that firms' risk management and financing policies had a significant impact on the degree to which firms were impacted by the financial crisis [3]. Because firms' risk management and financing policies are ultimately the result of cost-benefit trade off made by corporate boards and shareholders, an important implication from these studies is that corporate governance affected firm performance during the crisis period.

Corporate financing decisions are quite complex processes and existing theories can at best explain only certain facets of the diversity and complexity of financing choices. By demonstrating how competing hypotheses may dominate each other at different segments of the relevant data distribution reconcile some of the empirical irregularities reported in prior studies thereby cautioning the standard practice of drawing inferences on capital structure choices based on conditional mean estimates. By using productive efficiency as opposed to financial performance indicators as measure of (inverse) agency costs are able to carry out tests of the agency theory that are not confounded by factors that may not be related to agency costs.

*Corresponding author: Kahlil Fauzan, Department of Economics, MMSI Gunadarma University Depok, Jawa Barat, Indonesia, Tel: +622192116014; E-mail: kahlil_fauzan@rocketmail.com

Received March 29, 2018; Accepted April 05, 2018; Published April 12, 2018

Citation: Fauzan K, Kuswanto D (2018) The Effect of Capital Structure, GCG, CSR, Firm's Size on Market Value through Earnings Per Share in Banking Sector. J Glob Econ 6: 288. doi: 10.4172/2375-4389.1000288

Copyright: @ 2018 Fauzan K, et al. This is an open-access article distributed under the terms of the Creative Commons Attribution License, which permits unrestricted use, distribution, and reproduction in any medium, provided the original author and source are credited. 


\section{Methodology}

\section{Research subject}

Research on the subject of the research is the bank listed on the Indonesia Stock Exchange in 2008 to 2015 and reported self-assessment good corporate governance and disclose corporate social responsibility.

\section{Population and sampling technique}

The population in this research are all banks that have been listed on the Indonesia Stock Exchange in 2008. Sampling method that will be used in this research is purposive sampling method by taking samples that have been pre-determined in accordance with the research objectives (Table 1).

Based on purposive sampling method, then obtained 14 banks that become the subject in this research (Table 2).

\section{Result and Discussion}

\section{Path analysis}

Path analysis is an empirical procedure to estimate the closeness of dependency or causality relationship between observed variables. To perform path analysis, the path diagram illustrates the relation between the variables involved in the analysis in the form of visual display. In the path diagram there are arrows that connect between variables. Single-edged arrows describe the dependency relationship (influence) independent variable to the dependent variable. While double-edged arrows describe correlational or covariance between variables.

Unlike regression analysis, path analysis is not used to predict dependent variables based on independent variables. Path analysis is also not used to determine the set of independent variables that must be presented to predict the dependent variable (prediction function).

\begin{tabular}{|l|l|l|}
\hline No. & Description & Total \\
\hline 1 & $\begin{array}{l}\text { The Bank is already listed on the Indonesia Stock } \\
\text { Exchange in the year 2008 }\end{array}$ & 27 \\
\hline 2 & $\begin{array}{l}\text { The Bank reported self-assessment report of good } \\
\text { corporate governance from the year 2008 up to 2015 }\end{array}$ & -11 \\
\hline 3 & $\begin{array}{l}\text { The Bank did not experience any losses resulting in } \\
\text { earning per share negative from the year 2008 up to 2015 }\end{array}$ & -2 \\
\hline Total of Sample & 14 \\
\hline
\end{tabular}

Source: The data was processed.

Table 1: The sample selection process based on criteria

\begin{tabular}{|l|l|l|}
\hline No. & Entities Code & Name of Entities \\
\hline 1 & BBCA & Bank Central Asia \\
\hline 2 & BBKP & Bank Bukopin \\
\hline 3 & BBNI & Bank Negara Indonesia \\
\hline 4 & BBRI & Bank Rakyat Indonesia \\
\hline 5 & BDMN & Bank Danamon \\
\hline 6 & BKSW & Bank QNB Kesawan \\
\hline 7 & BMRI & Bank Mandiri \\
\hline 8 & BNGA & Bank CIMB Niaga \\
\hline 9 & BNLI & Bank Permata \\
\hline 10 & BTPN & Bank Tabungan Pensiunan Nasional \\
\hline 11 & INPC & Bank Artha Graha International \\
\hline 12 & MCOR & Bank Windu Kentjana International \\
\hline 13 & NISP & Bank OCBC NISP \\
\hline 14 & PNBN & Bank Pan Indonesia \\
\hline
\end{tabular}

Source: The data was processed.

Table 2: Subject of Research.
However, path analysis is only used to test the closeness of relationships among variables in the proposed model based on theoretical considerations (explanatory functions), and the relationships among variables tested are generally statistically causality or dependency relationships.

The advantage of path analysis versus regression analysis is in terms of its ability to determine the type of relation between independent variables when explaining its relationship with the dependent variable. Such relations may be correlational relations, mediation relations (intervening), as well as dependency relationships as usual regression analysis. However, to find which relationship model is most appropriate depends on the underlying theory.

In path analysis, correlational relation (covariance) in the form of double-edged arrow that connects exogenous variables is necessary, considering the method of calculating path coefficients based on the correlation between variables. Actually, there are some differences between the principles of regression analysis and path analysis. Once again do not assume that the difference is in the regression analysis there is the intercept while in path analysis do not exist. In regression analysis, the critical issue is to determine the best set of independent variables used to predict the dependent variable. Therefore, the specification of the model in regression analysis includes determining which variables are entered into the model, determine which variable is the independent variable and the dependent variable is which. Meanwhile, path analysis is not intended to find the model of cause and effect, but only used to test the theoretical relationship relationships between variables in General is the relationship causal or dependencies. In other words, path analysis is used to test the dependency relationship between the proximity of the variables. So, from the relationships between model already determined in advance based on the underlying theory. Path analysis of another is not the way to resolve the case of regression analysis involving mediation variables (intervening). Although the results of the analysis provide the same output, but determining when it should use regression analysis and when it should be using path analysis still depends on the design of the research [4] (Figure 1).

Based on the research framework already described in chapter II, author want to analysed path analysis in accordance with that has been done by previous researchers. Path analysis used in this research using application of statistic that is AMOS 20.

In that Figure 1 can see the path analysis with unstandardized estimates that output the output for regression weights for the default model. Each independent variable releases the regression value of each intervening variable, and the intervening variable releases the regression value of the dependent variable.

\section{Regression weight}

In regression weight can be seen that each independent variable releases the value of regression weight along with the level of significance $(\mathrm{P})$. The estimate value of Capital Structure to Earning per Share is -0.108 with significant level ${ }^{* * *}$ which means the probability of getting a critical ratio (C.R.) as large as 5,566 in absolute value is less than 0.001 . In other words, the regression weight for capital structure in the prediction of earning per share is significantly different from zero at the 0.001 level (two-tailed). The regression weight estimate, -0.108 , has a standard error (S.E) of about 0.019 (Table 3).

The estimate value of corporate social responsibility to Earning per Share is -0.078 with significance level 0.002 which means the probability of getting a critical ratio (C.R.) as large as 3.101 in absolute 


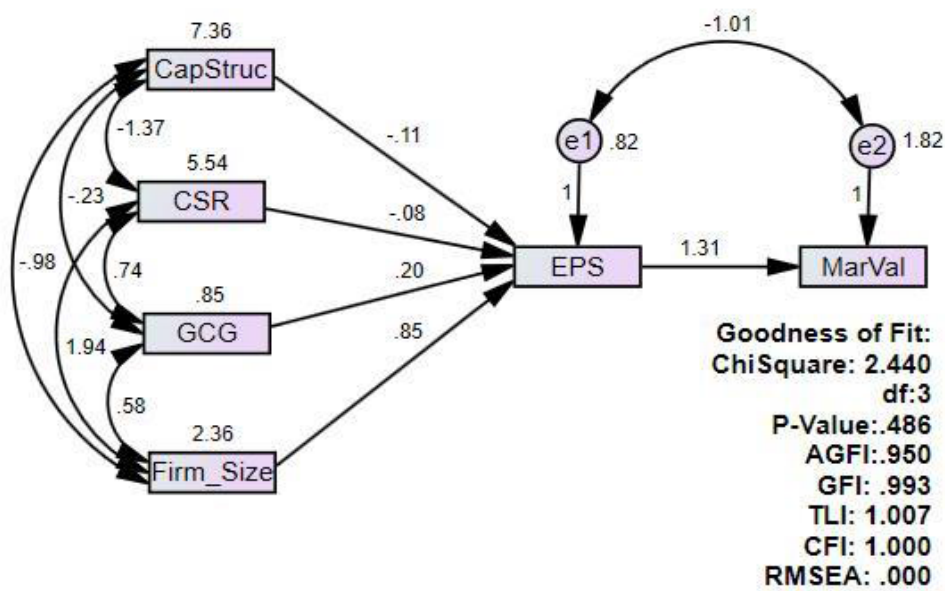

Figure 1: Path analysis with unstandardized estimates.

\begin{tabular}{|l|l|c|c|c|c|}
\hline & & Estimate & S.E. & C.R. & Label \\
\hline EPS & $<--$ & CapStruc & -0.108 & 0.019 & -5.566 \\
\hline EPS & $<---$ & CSR & -0.078 & 0.025 & -3.101 \\
\hline EPS & $<---$ & GCG & 0.202 & 0.06 & 0.002 \\
\hline EPS & $<---$ & Firm_Size & 0.855 & 0.059 & 3.381 \\
\hline MarVal & $<---$ & EPS & 1.309 & 0.092 & \\
\hline
\end{tabular}

Table 3: Regression weight.

value is 0.002 . In other words, the regression weight for corporate social responsibility in the prediction of earning per share is different from zero at the 0.01 level (two-tailed). The regression weight estimate, -0.078 , has a standard error (S.E) of about 0.025 .

The estimate value of good corporate governance to earnings per share is 0.202 with significance level ${ }^{* *}$ which means the probability of getting a critical ratio (C.R.) as large as 3,381 in absolute value is less than 0.001 . In other words, the regression weight for good corporate governance in the prediction of earning per share is the different from zero at the 0.001 level (two-tailed) [5]. The regression weight estimate, 0.202 , has a standard error (S.E) of about 0.060 .

The estimate value of firm size to earning per share is 0.855 with significance level ${ }^{* * *}$ which means the probability of getting a critical ratio (C.R.) as large as 14,527 in absolute value is less than 0.001 . In other words, the regression weight for firm size in the prediction of earning per share is the different from zero at the 0.001 level (twotailed). The regression weight estimate, 0.855 , has a standard error (S.E) of about 0.059 .

The estimate value of earnings per share to market value is 1,309 with significance level ${ }^{* * *}$ which means the probability of getting a critical ratio (C.R.) as large as 14.309 in absolute value is less than 0.001 . In other words, the regression weight for earnings per share in the prediction of market value is different from zero at the 0.001 level (two-tailed). The regression weight estimate, 1.309, has a standard error (S.E) of about 0.092 .

The unstandardized value is denoted by (b) and since this coefficient is a non-standardized coefficient, then the judgment cannot be based on the estimation value only the author should also look at the standard error value (S.E). If the high estimate value and the standard error value are high, the assessment of the model is also considered insignificant. The value of C.R. shows the critical ratio value obtained from the estimated value divided by the standard error (S.E). The higher the value of C.R, the more significant the research model.

The value of e 1 above the earning per share is 0.82 which shows the error value. The value of el indicates that this research model is suitable because of the small error value [6]. The smaller the error value generated by the intervening variable the more appropriate the selection of independent variables selected for the research model. The value of e 1 also shows that previous research on the variables studied in this research is very suitable for earning per share.

\section{Variance}

The value of e 2 above the market value is 1.82 which shows the error value. The value of $\mathrm{e} 2$ indicates that this research model is suitable because of the small error value. The smaller the error value generated by the intervening variable the more appropriate the selection of independent variables selected for the research model. The value of e2 also shows that previous research on the variables studied in this research is very suitable for market value (Table 4).

In variance can be seen the variance of each variable in this research. The variance of capital structure is estimated to be 7.362 has a standard error of about 0.988 and dividing the variance estimate by the estimate of its standard error gives $\mathrm{z}=7.362 / .988=7.450$. In other words, the variance estimate is 7.45 standard errors above zero. The probability of getting a critical ratio as large as 7.45 in absolute value is less than 0.001. In other words, the variance estimate for capital structure is significantly different from zero at the 0.001 level (two-tailed).

The variance of CSR is estimated to be 5.545 has a standard error of about 0.744 and dividing the variance estimate by the estimate of its standard error gives $\mathrm{z}=5.545 / .74=7.450$. In other words, the variance estimate is 7.45 standard errors above zero. The probability of getting a critical ratio as large as 7.45 in absolute value is less than 0.001 . In 
Citation: Fauzan K, Kuswanto D (2018) The Effect of Capital Structure, GCG, CSR, Firm's Size on Market Value through Earnings Per Share in Banking Sector. J Glob Econ 6: 288. doi: 10.4172/2375-4389.1000288

Page 4 of 7

other words, the variance estimate for corporate social responsibility is significantly different from zero at the 0.001 level (two-tailed).

The variance of GCG is estimated to be 0.846 has a standard error of about 0.114 and dividing the variance estimate by the estimate of its standard error gives $\mathrm{z}=0.846 / 0.114=7.450$. In other words, the variance estimate is 7.45 standard errors above zero. The probability of getting a critical ratio as large as 7.45 in absolute value is less than 0.001 . In other words, the variance estimate for good corporate governance is significantly different from zero at the 0.001 level (two-tailed).

The variance of Firm Size is estimated to be 2.356 has a standard error of about 0.316 and Dividing the variance estimate by the estimate of its standard error gives $z=2.356 / 0.316=7.450$. In other words, the variance estimate is 7.45 standard errors above zero (Figure 2). The probability of getting a critical ratio as large as 7.45 in absolute value is less than 0.001. In other words, the variance estimate for firm's size is significantly different from zero at the 0.001 level (two-tailed).

In path analysis with standardized estimates can see the path analysis with standardized estimates that output for the standard regression weights for the default model [7]. Each independent variable excludes the standard values of each intervening variable, and the intervening variable outputs the standard value against the dependent variable.

\begin{tabular}{|c|c|c|c|c|}
\hline & Estimate & S.E. & C.R. & P Label \\
\hline CapStruc & 7.362 & 0.988 & 7.45 & $* * *$ \\
\hline CSR & 5.545 & 0.744 & 7.45 & $* * *$ \\
\hline GCG & 0.846 & 0.114 & 7.45 & $* * *$ \\
\hline Firm_Size & 2.356 & 0.316 & 7.45 & $* * *$ \\
\hline e1 & 0.825 & 0.111 & 7.45 & $* * *$ \\
\hline e2 & 1.825 & 0.307 & 5.943 & $* * *$ \\
\hline
\end{tabular}

Source: The data was processed.

Table 4: Variance.

\begin{tabular}{|lll|c|}
\hline & & Estimate \\
\hline EPS & $<--$ & CapStruc & -0.175 \\
\hline EPS & $<--$ & CSR & -0.111 \\
\hline EPS & $<--$ & GCG & 0.111 \\
\hline EPS & $<---$ & Firm_Size & 0.786 \\
\hline MarVal & $<--$ & EPS & 1.099 \\
\hline
\end{tabular}

Source: The data was processed.

Table 5: Standardized regression weights.

\section{Standardized regression weights}

In standardized regression weights can be seen that each variable issued the value of standard regression weight. The standardized value is denoted by $(\beta)$. Standardized values can be used to compare how influential each independent variable is to the intervening, and how influential the intervening variable is to the dependent variable. The author can create 2 equation models of the standardized value (Table 5).

The value of capital structure against earnings per share is -0.175 which means when capital structure goes up by 1 standard deviation, earnings per share goes down by 0.175 standard deviations.

The value of good corporate governance against earnings per share is 0.111 which means that when good corporate governance goes up by 1 standard deviation, earnings per share goes up by 0.111 standard deviations.

The value of corporate social responsibility against earnings per.

\section{Hypothesis testing}

Based on the research model on chapter II, it can be formulated as the following hypothesis:

Share is -0.111 which means when corporate social responsibility goes up by 1 standard deviation, earnings per share goes down by 0.111 standard deviations.

The firm's size value against earnings per share is 0.786 which means when firm's size goes up by 1 standard deviation, earnings per share goes up by 0.786 standard deviations. The value of earning per share against market value is 1.099 which means that when earnings per share goes up by 1 standard deviation, market value goes up by 1,099 standard deviations.

\section{Squared multiple correlations}

In squared multiple correlations can be seen the squared multiple correlations. It is estimated that the predictors of EPS explain 70.4 percent of its variance. In other words, the error variance of earnings per share is approximately 29.6 percent of the variance of EPS itself. It is estimated that the predictors of MarVal explain 53.9 percent of its variance. In other words, the error variance of Market Value is approximately 46.1 percent of the variance of market value itself (Table 6).

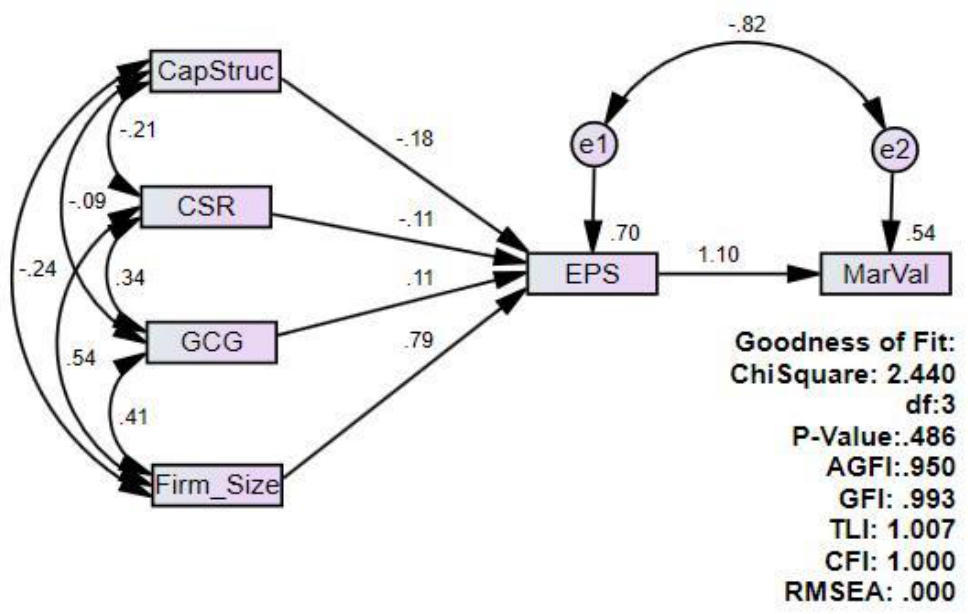

Figure 2: Path analysis with standardized estimates. 


\begin{tabular}{|l|c|}
\hline & Estimate \\
\hline EPS & 0.704 \\
\hline MarVal & 0.539 \\
\hline
\end{tabular}

Table 6: Squaared multiple correlations.

H1: There is the influence of capital structure against market value through earning per share.

$\mathrm{H} 2$ : There is the influence of good corporate governance against market value through earning per share.

H3: There is the influence of corporate social responsibility against market value through earning per share.

H4: There is the influence of firm size against market value through earning per share. value.

H5: There are influences from earning per share against market

\section{Effect of capital structure against on value through earning per share}

Based on the results in path analysis that is table regression weights. In regression weights can be seen that each independent variable releases the value of regression weight along with the level of significance $(\mathrm{P})$. The estimate value of Capital Structure to Earning per Share is -0.108 with significant level ${ }^{* * *}$ which means the probability of getting a critical ratio (C.R.) as large as 5,566 in absolute value is less than 0.001 . In other words, the regression weight for capital structure in the prediction of earning per share is significantly different from zero at the 0.001 level (two-tailed). The regression weight estimate, -0.108 , has a standard error (S.E) of about 0.019 . With significance level ${ }^{\star * *}$ then accepted.

\section{Effect of good corporate governance on market value through earning per share}

Based on the results in path analysis that is table regression weights. In regression weights can be seen that each independent variable releases the value of regression weight along with the level of significance (P). The estimate value of good corporate governance to earnings per share is 0.202 with significance level ${ }^{* *}$ which means the probability of getting a critical ratio (C.R.) as large as 3,381 in absolute value is less than 0.001 . In other words, the regression weight for good corporate governance in the prediction of earning per share is the different from zero at the 0.001 level (two-tailed). The regression weight estimate, 0.202 , has a standard error (S.E) of about 0.060 . With significance level *** then accepted.

\section{Effect of corporate social responsibility on market value through earning per share}

Based on the results in path analysis that is table regression weights. In regression weights can be seen that each independent variable releases the value of regression weight along with the level of significance $(\mathrm{P})$. The estimate value of corporate social responsibility to earning per share is -0.078 with significance level 0.002 which means the probability of getting a critical ratio (C.R.) as large as 3.101 in absolute value is 0.002 . In other words, the regression weight for corporate social responsibility in the prediction of earning per share is different from zero at the 0.01 level (two-tailed). The regression weight estimate, -0.078 , has a standard error (S.E) of about 0.025 . With a significance level of 0.002 then accepted.

\section{Effect of firm's size on market value on earning per share}

Based on the results in path analysis that is table regression weights. In regression weights can be seen that each independent variable releases the value of regression weight along with the level of significance $(\mathrm{P})$. The estimate value of firm size to earning per share is 0.855 with significance level ${ }^{* * *}$ which means the probability of getting a critical ratio (C.R.) as large as 14,527 in absolute value is less than 0.001 . In other words, the regression weight for firm size in the prediction of earning per share is the different from zero at the 0.001 level (two-tailed). The regression weight estimate, 0.855 , has a standard error (S.E) of about 0.059 . With significance level ${ }^{\star * *}$ then accepted.

\section{Effect of per share on market value}

Based on the results in path analysis that is table regression weights. In regression weights can be seen that each independent variable releases the value of regression weight along with the level of significance (P). The estimate value of earnings per share to market value is 1,309 with significance level which means the probability of getting a critical ratio (C.R.) as large as 14.309 in absolute value is less than 0.001 [8,9]. In other words, the regression weight for earnings per share in the prediction of market value is different from zero at the 0.001 level (two-tailed). The regression weight estimate, 1.309 , has a standard error (S.E) of about 0.092. With significance level ${ }^{* *}$ then accepted [10-12].

\section{Discussion}

The research aims to analyse the effect of capital structure, good corporate governance, corporate social responsibility, firm's size on earnings per share. In Table 6 can be seen that each variable issued the value of standard regression weight. The standardized value is denoted by ( ). Standardized values can be used to compare how influential each independent variable is to the intervening, and how influential the intervening variable is to the dependent variable.

The value of capital structure against earnings per share is -0.175 which means when capital structure goes up by 1 standard deviation, earnings per share goes down by 0.175 standard deviations. This shows that an increase in capital structure will reduce earnings per share, the relationship between capital structure with earnings per share inversely proportional. The higher the capital structure (debt/capital) value, the more unfavorable the bank's ability to pay its own debt is harder to pay and this will also have an impact on the bank's earnings. Agreement with related parties to pay off the debt should be a bank because the bank is the most commonly used financial institution of society.

The value of good corporate governance against earnings per share is 0.111 which means that when good corporate governance goes up by 1 standard deviation, earnings per share goes up by 0.111 standard deviations. This shows that the increasing capital structure will increase earnings per share, the relationship between the good corporate governance with earnings per share is directly proportional. Corporate governance is something always seen by stakeholders either shareholders, financial analysts, tax employee. 11 aspects assessed in bank governance are important aspects to be studied. In addition, other information related to the implementation of good corporate governance of Banks beyond the 11 evaluation factors of good corporate governance implementation such as problems arising from the impact of remuneration policy on a bank or internal disputes that interfere with the Bank's operational continuity. For example, the determination of bonuses based on the achievement of targets at the end of the year, where targeting is very high (ambitious), resulting in unhealthy practices by management or bank employees in achievement. 
The value of corporate social responsibility against earnings per share is -0.111 which means when corporate social responsibility goes up by 1 standard deviation, earnings per share goes down by 0.111 standard deviations. This shows that the increasing activity in corporate social responsibility will reduce earnings per share, the relationship between corporate social responsibility with earnings per share inversely proportional. The accounting treatment of CSR activities only focuses on environmental conditions alone, not on other activities such as scholarship donations, health, culture, sports, or other activities. In the Law of the Republic of Indonesia number 40 of 2007 discussed about limited liability company on Social and Environmental Responsibility which is expected to realize sustainable economic development to improve the quality of life and environment that benefit the Company itself, local community, and society in general. This provision applies to support the establishment of the harmonious, balanced, and appropriate relationships with the local community's environment, values, norms and cultures, then it is determined that what is going on in the field and/ or in connection with natural resources shall be carried out for Social and Environmental Responsibility. In order to do so, the activities of Social and Environmental Responsibility should be budgeted and calculated as a cost that is possessed by due regard to decency and fairness. Within the regulation, it is not explained that CSR activities are charged as operating expenses or non-operating expenses. So for the accounting treatment, the authors can conclude that corporate social responsibility activities into operational costs (other expenses) and reduce profits.

Corporate Social Responsibility (CSR) is implemented in several companies by executing several activities or programs, where the activities are related to and related to the financial company. As in the rules and regulations of the accounting rules, any activity undertaken by the company should be reported. Until now the company's annual report, reporting on Corporate Social Responsibility (CSR) was limited to narrative and budget, not described in detail the costs and benefits of the company's entry is treated as an expense.

In the Financial Accounting Standards for Entities without Public Accountability (SAK-ETAP) described expenses that include losses and expenses incurred in the normal course of activity of an entity. Expenses incurred in the normal course of business activities include cost of goods sold, wages and depreciation. The expenses are usually in the form of an outflow or decrease in assets such as cash and cash equivalents, inventories, and fixed assets. Losses reflect other items that meet the definition of expenses that may or may not arise in the normal course of activity of the entity. When losses are recognized in the income statement it is usually presented separately because the knowledge of the post is useful for the purpose of decision making. In addition, the recognition of expenses in SAK-ETAP is recognized in the profit and loss statement if future declines in economic benefits related to asset losses or liabilities increase have occurred and can be measured reliably. The accounting treatment performed by banks related to CSR costs is in accordance with SAK-ETAP. Because the fees charged in CSR activities are presented and recognized within a certain period. In addition, the fees charged are recognized, presented and disclosed in accordance with the function of each cost. Although the costs presented and disclosed are still items that represent cost activities and there is still no specific account related to CSR activities. So the reported cost activity can be well analyzed. In SAK-ETAP also described an entity does not have to specifically regulate and report the costs incurred as long as the information provided can provide information relevant to the user needs of decision makers, in addition to the information presented relating to costs must also be presented reliably.
The firm's size value against earnings per share is 0.786 which means when firm's size goes up by 1 standard deviation, earnings per share goes up by 0.786 standard deviations. This indicates that the larger firms size the greater the earnings per share, the relationship between firm's size with earnings per share is directly proportional Firm size has been empirically found to be strongly positively related to earnings per share. A number of intuitive explanations can be put forward to account for this stylized fact, but none have been considered theoretically. Firm size has become such a routine to use as a control variable in empirical corporate finance studies it receives little to no discussion in most research papers even though not uncommonly it is among the most significant variables. That large companies are under pressure to reveal their activity to legitimize their businesses. Large companies do more activities, have a greater impact on the community, have shareholders who may be concerned with the environmental program undertaken by the company, and their annual report is more efficient in communicating such information to stakeholders. Large companies are companies mostly highlighted by the public so greater disclosure is a form of corporate responsibility which is reflected from earnings per share.

The research aims to analyse the effect of earnings per share on market value. The value of earning per share against market value is 1.099 which means that when earnings per share goes up by 1 standard deviation, market value goes up by 1,099 standard deviations. This shows that the more earnings per share the more market value, the relationship between earnings per share and market value is directly proportional. Earnings per share reflects the book value reported by the bank, the real value of the bank is the market value. It can be indicated that the capital market in Indonesia gives higher value to the bank due to the strength of bank income. If the bank has profits consistently will have a market value greater than the book value of the bank. Based on the research and discussion that has been done on the object of research, then the author can provide a conclusion that:

1. Capital structure, good corporate governance, corporate social responsibility and firm's size have an influence on earnings per share. The relationship between capital structure with earnings per share inversely proportional. The relationship between the good corporate governance with earnings per share is directly proportional. The relationship between corporate social responsibility with earnings per share inversely proportional. The relationship between firm's size with earnings per share is directly proportional.

2. Earnings per share have an influence on market value. This shows that the more earnings per share the more market value, the relationship between earnings per share and market value is directly proportional. Earnings per share reflects the book value reported by the bank, the real value of the bank is the market value. It can be indicated that the capital market in Indonesia gives higher value to the bank due to the strength of bank income.

Based on the results of this research, then the author can give recommendation that the higher the capital structure (debt/capital) value, the more unfavourable the bank's ability to pay its own debt is harder to pay and this will also have an impact on the bank's earnings. Agreement with related parties to pay off the debt should be a bank because the bank is the most commonly used financial institution of society. Corporate governance is something always seen by stakeholders either shareholders, financial analysts, tax employee. 11 aspects assessed in bank governance are important aspects to be studied. Indonesia's regulation on the imposition of fees for CSR is not clear enough, as it is unclear in the regulation that CSR activities are 
Citation: Fauzan K, Kuswanto D (2018) The Effect of Capital Structure, GCG, CSR, Firm's Size on Market Value through Earnings Per Share in Banking Sector. J Glob Econ 6: 288. doi: 10.4172/2375-4389.1000288

charged as operational or non-operational costs. Large companies are companies mostly highlighted by the public so greater disclosure is a form of corporate responsibility which is reflected from annual report. Earnings per share reflects the book value reported by the bank, the real value of the bank is the market value. It can be indicated that the capital market in Indonesia gives higher value to the bank due to the strength of bank income. If the bank has profits consistently will have a market value greater than the book value of the bank.

\section{References}

1. Grove H, Patelli L, Victoravich LM, Xu P (2011) Corporate governance and performance in the wake of the Financial Crisis: Evidence from US Commercial Banks. Corporate Governance: An International Review 19: 418-436.

2. Taylor JB (2009) The Financial Crisis and the Policy Responses: An Empirical Analysis of What Went Wrong. Crit. Rev. 21: 341-364.

3. Brunnermeier M (2009) Deciphering the liquidity and credit crunch $2007-2008$ J Econ Perspect 23: 77-100.

4. Dachlan U, Panduan L, Semarang LI (2014) Structural Equation Modelling

5. World Bank, (2002). SME World Bank Group Review of Small Business. Activities. Washington, DC: World Bank.
6. Law of the Republic of IndonesiaN 40 of 2007 concerning Limited Liability Companies.

7. Financial Accounting Standards Entity Without Public Accountability, May 2009.

8. Bank Indonesia regulation Number 8/14/2006 concerning implementation of good corporate governance for commercial banks.

9. Utama CA (2012) Company disclosure in Indonesia: Corporate governance practice, ownership structure, competition and total assets. Asian journal of business and accounting.

10. Estiasih, SP, Oetomo HW, Asyik NF, Riduwan A (2015) The Influence of Corporate Social Responsibility and Good Corporate Governance on Firm Value: The Characteristic of the Company as Moderating Variable. International Journal of Business and Behavioural Sciences 5:11-23.

11. Suhermin A (2014) The effect of intellectual capital on stock price and company value in manufacturing companies listed in Indonesia Stock Exchange 2008-2012 with size and leverage as moderating variables. The Indonesian Accounting Review 4:157-168.

12. Mai MU (2017) Mediation of CSR and Profitability on the Influences of GCG Mechanisms to the Firm Value. Journal of Finance and Banking. 